\author{
Рајна М. ДРАГИЋЕВИЋ* \\ Милош В. УТВИЋ ${ }^{* *}$ \\ Филолошки факултет \\ Универзитета у Београду
}

\title{
ПЕСНИЧКИ РЕЧНИК ИРЕНЕ ГРИЦКАТ
}

\begin{abstract}
У раду се бавимо избором лексике Ирене Грицкат у збирци песама Циклоида и указујемо на везу између њене поезије, посебно лексике у њој, са закључцима у њеним лингвистичким истраживањима и размишљањима у есејима које је посветила науци. У раду се објављује и фреквенцијски речник аутосемантичних лексема употребљених у овој збирци, чиме се та лексика даје на увид читаоцима и омогућава лакши приступ за даљу анализу.
\end{abstract}

Кључне речи: Ирена Грицкат, мисаона поезија, фреквенцијски речник, лексика, лексикологија, лексикографија, српски језик.

1. УводНА РАЗмАТРАњА. Прошле године (2019), навршило се десет година од смрти уваженог српског лингвисте, академика Ирене Грицкат. За њом је остала библиографија од 260 библиографских јединица, коју углавном сачињавају лингвистичка истраживања, али и есеји, преводи, аутобиографија, збирка песама. Ирена Грицкат је била врсни лексикограф, али и уважени стручњак за српски језик панхронијске оријентације. Бавећи се и савременим српским језиком и историјом језика, усавршавала је и сопствену лексичку креативност. Томе је додатно доприносила чињеница што је била билингвална (исп. нпр. Арсењев 2010), па је своју лексику захватала из два словенска језичка изворишта. Када се све ове чињенице узму у обзир, тешко је остати равнодушан према збирци песама Ирене Грицкат, а радозналост и очекивања велика су и пре него што се читалац посвети њеним стиховима.

Предмет овог рада, у ширем смислу, представља лексика у збирци песама Циклоида Ирене Грицкат (Београд: Народна књига, 2002). Збирку сачињава 28 песама. Део уводне студије у зборнику радова Ирене Грицкат (Драгићевић 2020б: 9-45, о И. Г. као песникињи: 33-40) посветили смо углавном творбеном аспекту лексике из ове збирке, као и степену њене потврђености

\footnotetext{
*rajna.dragicevic@fil.bg.ac.rs

***milos.utvic@fil.bg.ac.rs
} 
у постојећим речницима српског језика. Циљ овога рада јесте двојак. На једној страни, покушаћемо да покажемо до које мере је Ирена Грицкат кроз своју поезију показала основно начело духовног живота о којем је писала у неким својим радовима (исп. нпр. Грицкат 1986), а које подразумева да су уметност, наука, религија и сви остали облици духовности повезани истим нитима, истим покретачима и потрагом за истим истинама. У песмама Ирене Грицкат откривамо исте идеје о којима је писала у својим есејима о науци, као и у својим лингвистичким радовима, а оне су нарочито читљиве кроз лексику тих песама. Други циљ овога рада јесте да се представи фреквенцијски речник аутосемантичних лексема (именица, придева, глагола и прилога) из песничке збирке Ирене Грицкат и да се тиме омогуће даља истраживања ове необичне, пажљиво одабране лексике. ${ }^{1}$

2. ПриПРемА коРПУСА. Корпус песама збирке Циклоида (у даљем тексту: корпус) настајао је у неколико корака. Студенти Катедре за библиотекарство и информатику су у оквиру предмета Дигитални текст 2 добили као задужење да прекуцају текст са фотографија страница збирке, тако да се јасно могу идентификовати стихови, строфе и наслови песама. Добијени текстови су спојени, кориговани и анотирани. Најпре је примењена аутоматска анотација структуре на неколико нивоа (корпус, песма, наслов песме, строфа, стих) применом XML-елемената (body, div, head, $l g, l$ ), при чему су структурни нивои аутоматски нумерисани (вредност XML-атрибута $i d$ ) ради касније лакше идентификације и екстракције строфа и стихова који садрже одређену лему. Проналажење стихова који садрже одређену лему захтевало је и морфолошку анотацију корпусних речи, ограничену на придруживање информација о одговарајућој леми и врсти речи. Током морфолошке анотације искоришћен је систем електронских морфолошких речника (у даљем тексту: СМР), чији су аутори Цветана Крстев и Душко Витас (Крстев 2008), при чему су комбиноване аутоматска и ручна морфолошка анотација на следећи начин:

1) Коришћењем алата Unitex (Помије 2016) направљен је пресек текстова корпуса и СМР-а, на основу чега су одређена два скупа: 1) скуп одредница СМР-а чији облици хомографски одговарају некој текстуалној речи у корпусу („корпусне речи препознате СМР-ом”) и 2) скуп корпусних речи које хомографски не одговарају ниједној одредници СМР-а („непрепознате корпусне речи”). Пошто је речник „препознатих корпусних речи” подскуп CMP-а, непосредно је генерисан његов дериват, састављен од тројки облика (корпусна реч, врста речи, лема). При томе су се у речнику „препознатих корпусних речи" нашле и леме које су заиста присутне у корпусу, али и оне које заправо нису, већ случајно имају облик који је хомографски исти као нека корпусна реч. Речник „препознатих корпусних речи” потом је допуњен „непрепознатим корпусним речима” (укупно 181) којима је ручно придружена информација о леми и врсти речи. Тако добијени речник означаваћемо у даљем тексту као „проширени речник корпуса”.

\footnotetext{
${ }^{1}$ Корпус за ово истраживање, као и фреквенцијски речник начинио је и у раду описао Милош Утвић, а лексичке анализе обавила је и описала Рајна Драгићевић.
} 
2) С обзиром на то да је корпус релативно мали (педесетак страница текста) и да је током корекције прекуцани текст у целини прочитан, из „проширеног речника корпуса" елиминисане су поједине леме ниске учесталости за које се поуздано знало да их нема у речнику. Елиминисане су, пре свега, леме којих нема у корпусу, а чији се облици хомографски поклапају са облицима високофреквентних лема, како би се касније смањиле исправке после аутоматске анотације. На пример, ниједна корпусна реч ми није облик глагола мити, већ лична заменица ми; свака корпусна реч ли је представљала речцу, а не облик глагола лити; корпусна реч сад је увек коришћена као прилог, а не као именица итд.

3) Укрштањем корпуса и „проширеног речника корпуса” свакој корпусној речи је аутоматски придружен један или више парова (лема, врста речи), а потом су ручно елиминисани сувишни парови на основу контекста корпусне речи. У појединим случајевима, када је у „проширеном речнику корпуса” постојао само један могући пар (лема, врста речи) који се могао придружити корпусној речи, на пример (распрснути, глагол) за корпусну реч распрснућу, на основу ширег контекста се показало да то не мора бити исправан пар (распрснуће, именииа) који није био присутан у коришћеној верзији СМР-а. Пошто се унапред знало да ћемо анализу корпуса ограничити на именице, глаголе, придеве и прилоге, у појединим случајевима вишезначности, где је било потребно одлучити се да ли је нешто предлог, речца или везник, питање врсте речи је остало неразрешено.

Анализом структурно и морфолошки анотираног корпуса израчуната је расподела лема и корпусних речи (облика) по различитим врстама речи (Табела 1), одређене учестаности лема и генерисане три верзије фреквенцијског речника корпуса у зависности од начина сортирања (алфабетски сортиран речник по леми, обратни речник и фреквенцијски речник сортиран по опадајућој учестаности).

Табела 1: Расподела лема и корпусних речи (облика) по различитим врстама речи

\begin{tabular}{|c|c|c|}
\hline Токени & Корпусне речи & Интерпункција \\
\hline 5.274 & 4.112 & 1.162 \\
\hline Врста речи & Број лема & Број облика \\
\hline Именице & 649 & 1.054 \\
\hline Глаголи & 396 & 819 \\
\hline Придеви & 400 & 554 \\
\hline Прилози & 121 & 305 \\
\hline Заменице & 38 & 405 \\
\hline Бројеви & 4 & 20 \\
\hline
\end{tabular}




\begin{tabular}{|c|c|c|}
\hline Предлози & 36 & 360 \\
\hline Везници & 21 & 348 \\
\hline Узвици & 5 & 7 \\
\hline Речце & 15 & 195 \\
\hline Неразрешено & 5 & 45 \\
\hline Укупно & 1.690 & 4.112 \\
\hline
\end{tabular}

3.1. ОДРАЗ НАУЧНОГ МИШљЕњА НА ПОЕЗИЈУ. Песмама академика Ирене Грицкат може се приступити из више углова. Нас је заинтересовала чињеница да их није написао прави песник, што значи да представљају емоционални и интелектуални експеримент Ирене Грицкат. Оне су производ мисаоне игре једног научника, а не песника, и зато су другачије - оригиналне, посебне, препознатљиве по личном печату, настале с идејом да не буду објављене, ${ }^{2}$ непланирано „излетеле” из душе научника пребогатог емоционалношћу, колико и идејношћу.

Други разлог због којег ове песме привлаче пажњу лежи у чињеници да је њихов аутор био врсни лексикограф Речника САНУ, лексички најразноврснијег и најбогатијег речника савременог српског језика. Професионална оријентисаност на лексичко значење и на избор праве речи више је него очигледна у избору лексике у песмама. Већ при првом сусрету са било којом песмом, читаоцу постаје јасно да у крупном плану није само њен садржај већ и начин на који је он обликован. Висок ниво лексичке истанчаности не може остати непримећен, а повремено чак и доминира над садржајем песме.

У свим видовима духовног стваралаштва, у науци, уметности, религији, Ирена Грицкат је увиђала јединствене принципе. Проналазила је везу између математичког и језичког мишљења, уочила је тачке у којима се сусрећу Ајнштајн, пишући о науци, и владика Николај Велимировић, размишљајући о православљу (исп. Драгићевић 2020б: 29). Бавећи се уметношћу, пишући поезију, Ирена Грицкат је примењивала своја научна (лингвистичка и ванлингвистичка) начела. Један од разлога за испитивање њене поезије јесте и проналажење тих подударности и метода које је употребила како би своју најдубљу мисаоност прелила у поезију, односно научну идеју у уметнички доживљај.

Многа интересовања Ирене Грицкат немају везе са лингвистиком. Једна од њених преокупација јесу загонетке космогоније и размишљања о почетку настанка живота. О томе она размишља кроз своје есеје, на необичан научно-уметнички начин, интуитивно, радознало, али залазећи и у филозофију,

\footnotetext{
${ }^{2}$ Ирена Грицкат је подстицај за објављивање својих песама добила од Васе Павковића, колеге и пријатеља, лексикографа који је заједно с њом радио на Речнику САНУ, а који је као уредник библиотеке Алфа: Поезија Народне књиге, године 2002, објавио њену збирку песама Циклоида.
} 
физику и математику. Нека од тих размишљања објавила је у есеју Легенде о почетку (Грицкат 1986):

Није било мало оних чија је мисао допирала до једне наизглед величанствене, а у ствари, у самој чињеници конциповања, наивне двоумице. Морао је, гласи она, постојати почетак, јер се друкчије не може замислити - али је и пре почетка морало постојати нешто, јер се друкчије не може замислити. Ни једно ни друго се не може замислити, ни тако ни овако, пошто и једно и друго, у последњем исходу, вуче и у несмисао и у нову тајну. Поставка о свеопштој узрочности мудра је ствар, али залуд сва мудрост, када се ни почетак ни крај тог узрочног ланца не сагледавају. Међутим, најмање ћемо погрешити ако признамо да је наивно разрешавати све ово: недостаје нам нека координата ума, нека димензија логике (Грицкат 1986: 85-86).

Ирена Грицкат била је задивљена и замишљена над тим недостајућим „координатама ума, димензијама логике” и веровала је да се емоцијом може досегнути оно што се не може разумом:

И мислимо, упорно мислимо - како је то могло да се са потпуног мрака небића наједном нешто помери, да се намрешка та прва млечна копрена? Некога је ово питање упућивало у поезију, некога у религију, најсмелијег у несавладљиво чезнуће [...] Ми, који се тиме не бавимо, можемо само неким поетским уосећавањем, а не умом да прихватамо ове податке. Ево, читамо: иза тек једне звезде која сија у Великим Колима констатује се постојање око милион галаксија. А једна галаксија - то је обухват чији пречник може достизати бајовите димензије: на пример, једна радио-галаксија у Малом Лаву има такве титанске размере да и сама светлост путује по њој с краја на крај читавих двадесет милиона година (Грицкат 1986: 86-87).

Пишући о прапочетку, Ирена Грицкат (1986) спомиње првобитне разлоге, свемирске дубине, неизрециве брзине, извиднии послату у небиће, поноре којих се није дотакао ниједан облик постојања, пулсирање Васионе, пробијање људи ка тајни почетка, закорак у трајање, покушаје да се сљушти офизикаљеност са чудесности прапочетка, безбојни и безоблични хаос, прапочетни амбис. Повезала је Платонове Дијалоге и постулате астрофизике, Зевса и Њутна, легенде и науку, Библију и Буду.

И сва та размишљања о недокучивом и прапрвом прелила је и у своју поезију, нарочито у песму Казивање гностичара Василида о постању Свемира.

Пре првих дрхтаја и првих мена, Пре свих почетака и свих кончина, У незамислива, у тамна правремена Предбивствоваше једино Дубина,
То једно нешто, нечега Дубина, Предвечна, предстворена.

У својој самотничкој боли

Зажелела је она пламсај неког непознатог жара,

И почела је најзад светове да ствара

- Јер није имала овако шта да воли.

У 20 најфреквентнијих именица у песмама из збирке Циклоида спадају следеће: 1. ноћ (20), 2. Бог (12), 3. душа (11), 4. земља (11), 5. небо (11), 6. звезда (9), 7. крај (9), 8. Месеи (9), 9. људи (7), 10. море (7), 11. мрак (7), 12. свет (7), 13. човек (7), 14. вал (6), 15. век (6), 16. глава (6), 17. зора (6), 18. љубав (6), 19. мисао (6), 20. обруч (6), пут (6), сан (6), стаза (6), сунце (6), тама (6). 
Већ сам списак најучесталијих именица наговештава мисаони карактер песама из збирке Циклоида, али оцртава и њихов основни тематски и емоционални колорит, а то су усамљеност и туга. О томе нарочито сведочи најфреквентнија именица ноћ, као и њени синоними мрак и тама, који такође припадају листи најучесталијих именица. Ноћ, Бог, душа, земља, небо ... сликају амбијент у којем Ирена Грицкат смешта садржаје до којих долази „уосећавањем сазнатог”.

Ноћ је у песмама Ирене Грицкат најчешће употребљена у свом основном значењу - део дана од заласка до изласка сунца. Експресивност се постиже придевима који у садејству с именицом ноћ дочаравају тишину, тугу и безнадежност. Ноћ је мркла, беспробудна, отајствена, жална, тиха, пуста, јесена, тамна, поларна, бесконачна.

- Поларна ноћ нема краја (41)3.

- Поново тамна ноћ без зоре (38).

- Где тоне свет ка пустој ноћи (38).

- Ту нема речи, нема стиха, ноћ је тиха (32).

- И све је ноћ, и бездан све је (20).

- Не шуште сенке. Ноћ је беспробудна (16).

- Тишина мрклу ноћ не буди (5).

Дуга, тамна ноћ која нема краја, у коју се тоне, у којој се ћути, бездан као понор без дна и без-дан у којем никад не свиће - то је свет у којем се рађају мисли и осећања усамљене песникиње. Такав амбијент буди њене асоцијације на појаве које су изван онога што постоји, што јесте. Један од начина на који их дочарава јесу творенице са компонентом без-: безвучје, безгласје, безбрижје, безнаће, бесмрће, беспуће, бесповрат. За разлику од предлошко-падежних конструкција без гласа, без наде, без бриге, којима се одређује стање које прати време вршења радње, чини се као да грађењем именица од ових конструкција настају бесконачна стања, чије трајање и ефекат надилазе човекове способности праћења и разумевања:

- Сиренина песма у безвучје тоне (45).

- Изгнан би човек из вишњега раја / и безбројне веке кроз безнађа траја (28).

- И тамо, у бесмрћу, стоје њих двоје (37).

- У бесповрат ишле су лађе (47).

Сличан се ефекат недокучивости добија и употребом придева безбројан, безмеран, бесконачан, бескрајан, беспробудан:

- И безбројне веке кроз безнађе траје (28).

- Има вас много у безмерној бездани (28).

- У пучину клизнула стрмо и чемерно / у валовље безмерно (45).

- Дух усамљен жељно слути / бесконачну плавет зрачну (26).

- Тамо, у гибању бескрајних вала (45).

\footnotetext{
${ }^{3}$ Број у загради иза стихова који се наводе у овом раду представља страницу у збирци Циклоида са које је стих преузет.
} 
Утисак непојмљивости појаве постиже се и твореницама са префиксом пра-: правреме, праисконски, прапрви:

- У незамислива, у тамна правремена / Предбивствоваше једино дубина (6).

- Он дозва неке чудесне бионе / Из праисконске таме (32).

- Треба да властиту створеност волимо / Те да се Прапрвом захвално молимо (10).

Творенице са компонентама пред-, над- и речцом не- у песмама Ирене Грицкат, као и оне на без- и пра-, о којима је било речи до сада, такође су послужиле за именовање апстрактних, тајанствених, недокучивих, оностраних појава: предвечан, предстворен, предбивствовати; надоблачни, натчујни, натчулни, надмучити; небит, небиће, недосежан, неизбројив, неизбројан, немерни, неохватан, непребројан, несвагдағи, непојмљиво, невид-путања:

- То једно нешто, нечега Дубина / Предвечна, предстворена (6).

- Предбивствоваше једино Дубина (6).

- Прати нас натчујни звон (21).

- Слушај тај напев, натчулни и бајни (28).

- Жели мимьу дотакнути / истинитост надоблачну (26).

- Муку ће умети Господов син да надмучи (7).

- Саздана тамо, у космичкој небити (10).

- Где опет тихо у небиће тоне (40).

- За туђег жала присен недосежни (40).

- Бог смисли кружне, неизбројиве / Скаларе ,дуге, кретье, бројеве (32).

- И отиде светица срна на сребрне невид-путање (22).

Оваква лексика привлачи пажњу и у семантичком смислу, јер је речници најчешће не бележе, има широко и нејасно значење и углавном спада у оказионализме. Међу лексемама које нису забележене у речницима савременог српског језика, а спадају у круг речи за недокучиве појаве, својства, стања, налазе се и ове: беспробудан, ванразумски, даљнослутни, надмучити, надчујни, невид-путања, прапрви, предбивствовати, предвечан, предстворен.

3.2. ОДРАЗ СХВАТАњА О ЕКСПРЕСИВНОЈ КОЛОКАЦИЈИ НА ПОЕЗИЈУ. ИреНа ГрИЦКаТ је у своје стихове уградила и нека начела о којима је писала размишљајући о семантичким законитостима. Она је често истраживала синтагматски утицај који лексеме врше једна на другу, утичући једна другој на значење на начине који се понекад не могу лексикографски описати:

Речи могу да се употребљавају неограничено разнолико при слободном третирању њихових семантичких врела. Практично свака реч (осим граматикалних и помоћних) вероватно може да има неку померену службу - и сама фигуративна, а делимично у фигуративном окружењу, при чему је често тешко рећи шта од тога двога на шта утиче еманирајући у правцу оног другог своју сликовитост (Грицкат 2020 [1997]: 72).

Ирена Грицкат је често у својим радовима наводила примере из књижевности у којима се заједно појављују речи које су, како она каже, „у сукобу из 
кога резултира опште померање значења и стилска маркираност" (Грицкат 2020 [1967]: 397). То су случајеви који резултирају „некохерентношћу буквалног значења и оног које се према положају у тексту очекује” (Грицкат 2020 [1967]: 397). Овакве појаве она назива метасемијом. Наводи и објашњава бројне лексичке спојеве у којима се, на пример, на именицу наслања друга именица у облику посесивног генитива, чији се спој „не може толерисати без стилског ефекта": крпе облака. Следећи тип необичног споја представља колокација коју сачињава прелазни глагол и неодговарајући објекат: снег засипа тишину. У посебну групу Ирена Грицкат издваја лексичке спојеве с неочекиваним глаголом: бубао је кроз парк (уместо: ходао је кроз парк и бубао или ходао је кроз парк бубајући). Пажњу јој привлачи и неочекивани прилог уз придев или глагол: врело виолетан ваздух (исп. Грицкат 2020 [1967]: 397-398).

На више места, Ирена Грицкат наглашава да се значење „догађа”. Оно се рађа из лексичких спојева и понекад га је веома тешко прецизно, научно одредити јер га прималац прихвата и развија све његове слојеве и „присенке”, више интуитивно и емоционално него рационално. Због тога се лексикограф понекад налази у немогућој ситуацији да опише значење лексеме које обликује одређени контекст и које је непоновљиво у другим контекстима. Пред њим је задатак да „идентификује концепцију (или више њих) која је у дату реч нашом свешћу уграђена" (Грицкат 2020 [1997]: 69-70).

Уз прозор се прислонила бледа сенка зоре - све то представља 'варничење' између речи, 'пробојна смисаона пражњења', која су и некоректна при критеријуму буквалности, и изазовна за уметничко чуло. [...] А када Васко Попа описује белутак који је хитнут у ваздух, па је ишчезао, 'на земљу се није вратио, на небо се није попео... ено белутка ни на небу ни на земљи, самог себе слуша међу световима свет', то није приопштавање ни стварних призора и слика [...] белутак се овде не везује ни за шта од наше истовремене когниције, па опет изазива неку менталну, или неку емотивну реакцију, он је алегорија, симбол, подсећа на нешто неуловљиво, чак ствара емпатију. Значи да и та реч опет нешто значи узета заједно са својим реченичним одн. ширим контекстуалним окружењем (Грицкат 2020 [1997]: 72-73).

Тим сукобима неочекиваних лексичких избора користила се Ирена Грицкат у својим стиховима сликајући тако то нешто неуловљиво што изазива менталну и емотивну реакцију.

Ветар у њеним стиховима тече, сањари, арлауче, пљушти:

- И кружи, и кружи безбрижни ветар и тече (7).

- Лахори путем [ветар], сањари (7).

- Ветар арлауче, вије и тули (41).

- Кад пљушти ветар, кад киша веје (20).

Емоције, стања и особине персонификују се, а тим оживљавањем постиже се изразита експресивност:

- Можда за свим тим и мудрост се ваљь (13).

- Из юих се плаха знатижеља точи (16).

- И оде ужас, постиђен и глув (18). 
- И поче немир да му душом бриди (32).

- Иза светлог виђена зна да свене нада (43).

Оживљавају се и појаве:

- Песма се разноси као да уздише (28).

- Видиком броде сивих магла власи (40).

- Расвиће још се није зачело (43).

Неким именицама додају се неочекивани придеви: безбрижни ветар, гранитни завет, привид бледожути, плаха знатижеља, разбуктали дани, натчујни звон, распрсла сазвежђа.

Бавећи се лексикографијом, дефинишући значења речи, Ирена Грицкат се суочавала са значењима која се не могу обухватити дефиницијом. У својим научним радовима покушала је да таквим појавама додели лингвистички опис и објашњење. Оно што је описала у својим научним студијама демонстрирала је у својим стиховима, па тако поново пратимо једну од идеја Ирене Грицкат којој се стално враћала - да је духовни живот монолитан и да човек тражи одговоре на основна питања свог постојања и онда када се бави научним истраживањем, и када ствара уметничко дело и када у религији покушава да спозна себе.

3.3. ОДРАЗ СХВАТАњА О ЕКСПРЕСИВНОЈ ТВОРБИ РЕЧИ НА ПОЕЗИЈУ. КаО ШТО ЗаКОнитости које на неочекиван начин могу повезивати речи у синтагме и реченице, тако и неочекивани спојеви творбених морфема могу произвести унутрашњи сукоб који доводи до снажне експресивности:

Не само што спојеви самосталних речи могу стварати спецификоване значењске асоцијације уколико те речи по реалној логици ствари нису за спајање, него такве асоцијације могу производити и делови сложеница одн. изведеница, префикси и суфикси. Питање је само од ког момента одиста почињу да се остварују стилске појаве. [...] За посебни одабир суфикса нађени су код Ђоновића примери: крововље (м. кровови), очигледно са упирањем на скупину, збијеност кровова, као што би било у случају бродовље за разлику од бродови (Грицкат 2020 [1967]: 399).

И баш тим тумачењем изнетим у научном раду одгонетнућемо због чега Ирена Грицкат у својој поезији користи збирне именице брежје, звуковље, валовље уместо знатно учесталијег плуралног облика брегови, звукови, валови. И она је имала потребу да „упире на скупину, збијеност”:

- Он ћути стрпљиво у свом том лудом звуковљу (30).

- У пучину клизнула стрмо и чемерно / У валовље безмерно (45).

- Жар-птица преко брежја лети (16).

Ирена Грицкат је у својим песмама често оживљавала или први пут градила именице на -је које означавају човекова стања (безнађе, безбрижсе, безгласје, бесмрће) или атмосферска стања, доба дана (обзорје, запоноћје, раздане). 
Чини се као да је за потребе своје поезије та стања концептуализовала (и) као простор:

- Зурећи у запоноћје тамно (16).

- Сиренина песма у безвучје тоне (45).

- Обруч, хитнут у раздања (49).

- И тамо, у бесмрћу, стоје њих двоје (37).

- У безгласју чаме (32).

- Где одзвуции среће у безбрижју звоне (45).

- У источном обзорју васионе (40).

У неким случајевима просторно значење је сасвим очигледно, када се, на пример, птичије гнездо назива укрићем, чиме се истиче да је то место које служи за скривање: Нежно је скупљала попале птиће / носила тихо у своје укриће.

Ирена Грицкат је на тај начин, користећи творбени потенцијал суфикса -је за грађење именица са месним значењем (нпр. прибрежје, загорје, забрђе, поречје), оживела, „опросторила” стања без гласа, без смрти, без бриге, без звука и дала им могућност да буду пространства изван човека, у које човек може крочити и сасвим се утопити у њих, јер је желела да их представи као пространија од човека. Зашто је баш употребила суфикс -je, а не неки други суфикс за грађење именица са просторним значењем? Одговор би се могао потражити у чињеници да су предлошко-падежне конструкције склоне везивању за суфикс -jе, што се не односи на све остале суфиксе који служе за грађење именица са просторним значењем.

Сличан ефекат судара домена постиже се када се просторним суфиксом или просторном употребом суфикса означава време. Ако се време концептуализује као простор, у њега се може крочити, оно се може посматрати из даљине, у њега се може убацити предмет, па се том игром послужила и Ирена Грицкат.

4. ЗАкључАк. У овом раду тражили смо и пронашли оправдања за три аспекта избора, настанка и заједничке употребе лексике у поезији Ирене Грицкат. У првом делу анализе повезали смо научно-уметнички есеј Ирене Грицкат о постанку Космоса са њеним песмама у којима се бави истом темом. Задржали смо се на лексици (углавном оказионалној) коју је осмислила и употребила како би дочарала стање недокучивости, несазнатљивости, апсолутне удаљености.

У другом делу анализе скренули смо пажњу на лингвистичко истраживање Ирене Грицкат о синтагматским лексичким односима и начинима на које они утичу на значење лексема које сачињавају неочекиване, ретке, необичне колокације. Запажања из тог рада повезали смо са експресивним колокацијама које је Ирена Грицкат „произвела” у својим песмама, а затим смо, наводима из научних радова, објаснили њихову мотивисаност.

У трећем делу анализе повезали смо запажања и закључке Ирене Грицкат о експресивним спојевима творбених морфема приликом грађења лексема и такве, необичне, оригиналне спојеве између префикса и мотивних речи 
које је употребила у својим песмама. У научним истраживањима открили смо, дакле, њену мотивацију за грађење речи у поетском тексту.

\section{ИЗВОР}

Грицкат 2002: Ирена Грицкат, Циклоида, уредник Васа Павковић, Београд: Народна књига - Алфа.

\section{ЛИТЕРАТУРА}

Арсењев 2010: Алексей Борисович Арсеньев, „Заметки о билингвизме Ирины Георгиевны Грицкат-Радулович", Русский язык как инославянский, выпуск II, главный редактор Б. Станкович, Белград: Славистическое общество Сербии, 84-95.

Грицкат 1986: Ирена Грицкат, „Легенде о почетку”, Летопис Матице српске, јануар 1986, год. 162, књ. 437, св. 1, 85-98.

Грицкат 2020 [1967]: Ирена Грицкат, „Шта све значи значити”, у: Кругови Ирене Грицкат (семантичко-граматичка истраживања савременог сриског језика) (ур. Рајна Драгићевић), Београд: Савез славистичких друштава Србије, 69-77.

Грицкат 2020 [1997]: Ирена Грицкат, „Стилске фигуре у светлу језичких анализа", у: Кругови Ирене Грицкат (семантичко-граматичка истраживања савременог сриског језика) (ур. Рајна Драгићевић), Београд: Савез славистичких друштава Србије, 385-401.

Драгићевић 2020а: Рајна Драгићевић (ур.), Кругови Ирене Грицкат (семантичко-граматичка истраживања савременог српског језика), Београд: Савез славистичких друштава Србије.

Драгићевић 2020б: Рајна Драгићевић, „Научни и уметнички кругови Ирене Грицкат”, Кругови Ирене Грицкат (семантичко-граматичка истраживања савременог српског језика), уводна студија, Београд: Савез славистичких друштава Србије, 9-45.

Крстев 2008: Cvetana Krstev, Processing of Serbian - Automata, Texts and Electronic Dictionaries, Belgrade: Faculty of Philology, University of Belgrade.

Помије 2016: Sébastien Paumier, Unitex 3.1. User Manual. http://unitexgramlab. org/releases/3.1/man/Unitex-GramLab-3.1-usermanual-en.pdf. 
Прилог 1: Фреквенцијски речник именица, глагола, придева и прилога у збирци песама Циклоида Ирене Грицкат (2002)

\begin{tabular}{|c|c|c|c|}
\hline јесам, гл. (130) & бити, гл. (34) & знати (ce), гл. (24) & хтети, гл. (22) \\
\hline хтети, гл. (22) & ноћ, им. (20) & где, прил. (19) & све, прил. (17) \\
\hline све, прил. (17) & немати, гл. (15) & тамо, прил. (15) & још, прил. (14) \\
\hline још, прил. (14) & бог, им. (12) & имати, гл. (12) & већ, прил. (11) \\
\hline већ, прил. (11) & видети, гл. (11) & душа, им. (11) & земља, им. (11) \\
\hline земља, им. (11) & моћи, гл. (11) & небо, им. (11) & први, прид. (11) \\
\hline први, прид. (11) & сад, прил. (11) & волети, гл. (9) & звезда, им. (9) \\
\hline звезда, им. (9) & крај, им. (9) & мало, прил. (9) & Месец, им. (9) \\
\hline Месец, им. (9) & гледати, гл. (8) & други, прид. (8) & ићи, гл. (7) \\
\hline ићи, гл. (7) & једном, прил. (7) & људи, им. (7) & море, им. (7) \\
\hline море, им. (7) & мрак, им. (7) & последњи, прид. (7) & свет, им. (7) \\
\hline свет, им. (7) & стајати, гл. (7) & стати, гл. (7) & ту, прил. (7) \\
\hline ту, прил. (7) & човек, им. (7) & чудан, прид. (7) & чути, гл. (7) \\
\hline чути, гл. (7) & вал, им. (6) & век, им. (6) & глава, им. (6) \\
\hline глава, им. (6) & дати (ce), гл. (6) & зора, им. (6) & кад, прил. (6) \\
\hline кад, прил. (6) & љубав, им. (6) & мисао, им. (6) & морати, гл. (6) \\
\hline морати, гл. (6) & најзад, прил. (6) & никад, прил. (6) & обруч, им. (6) \\
\hline обруч, им. (6) & опет, прил. (6) & отићи, гл. (6) & пут, им. (6) \\
\hline пут, им. (6) & рећи, гл. (6) & сан, им. (6) & слушати (се), гл. (6) \\
\hline слушати (се), гл. (6) & стаза, им. (6) & сунце, им. (6) & тама, им. (6) \\
\hline тама, им. (6) & газда, им. (5) & далеко, прил. (5) & дан, им. (5) \\
\hline дан, им. (5) & живот, им. (5) & зрак, им. (5) & исти, прид. (5) \\
\hline исти, прид. (5) & магла, им. (5) & небески, прид. (5) & незнан, прид. (5) \\
\hline незнан, прид. (5) & носити (се), гл. (5) & око, им. (5) & песма, им. (5) \\
\hline песма, им. (5) & поглед, им. (5) & поново, прил. (5) & почети, гл. (5) \\
\hline почети, гл. (5) & сада, прил. (5) & сам, прид. (5) & тада, прил. (5) \\
\hline тада, прил. (5) & тихо, прил. (5) & тонути, гл. (5) & тражити, гл. (5) \\
\hline тражити, гл. (5) & ходити, гл. (5) & божји, прид. (4) & ветар, им. (4) \\
\hline
\end{tabular}




\begin{tabular}{|c|c|c|c|}
\hline ветар, им. (4) & више, прил. (4) & властит, прид. (4) & дно, им. (4) \\
\hline дно, им. (4) & драг, прид. (4) & желети, гл. (4) & знање, им. (4) \\
\hline знање, им. (4) & играти (се), гл. (4) & ирвас, им. (4) & једанпут, прил. (4) \\
\hline једанпут, прил. (4) & како, прил. (4) & људски, прид. (4) & мах, им. (4) \\
\hline мах, им. (4) & много, прил. (4) & моћ, им. (4) & нов, прид. (4) \\
\hline нов, прид. (4) & овде, прил. (4) & пловити, гл. (4) & птица, им. (4) \\
\hline птица, им. (4) & светао, прид. (4) & свод, им. (4) & слух, им. (4) \\
\hline слух, им. (4) & стена, им. (4) & страна, им. (4) & судбински, прид. (4) \\
\hline судбински, прид. (4) & тад, прил. (4) & тако, прил. (4) & тишина, им. (4) \\
\hline тишина, им. (4) & час, им. (4) & шума, им. (4) & бездан, им. (3) \\
\hline бездан, им. (3) & безмеран, прид. (3) & беспуће, им. (3) & бродити, гл. (3) \\
\hline бродити, гл. (3) & васељена, им. (3) & велик, прид. (3) & веровати, гл. (3) \\
\hline веровати, гл. (3) & весео, прид. (3) & видик, им. (3) & вода, им. (3) \\
\hline вода, им. (3) & глув, прид. (3) & гора, им. (3) & гром, им. (3) \\
\hline гром, им. (3) & далек, прид. (3) & даљни, прид. (3) & добар, прид. (3) \\
\hline добар, прид. (3) & дубоко, прил. (3) & дух, им. (3) & живети, гл. (3) \\
\hline живети, гл. (3) & животан, прид. (3) & збити (се), гл. (3) & звездан, прид. (3) \\
\hline звездан, прид. (3) & звук, им. (3) & једини, прид. (3) & јелен, им. (3) \\
\hline јелен, им. (3) & кренути (се), гл. (3) & крик, им. (3) & крило, им. (3) \\
\hline крило, им. (3) & кружити, гл. (3) & лак, прид. (3) & лежати, гл. (3) \\
\hline лежати, гл. (3) & лепота, им. (3) & лет, им. (3) & летети, гл. (3) \\
\hline летети, гл. (3) & мајка, им. (3) & маскарада, им. (3) & мир, им. (3) \\
\hline мир, им. (3) & музика, им. (3) & мук, им. (3) & обзорје, им. (3) \\
\hline обзорје, им. (3) & одједном, прил. (3) & олуја, им. (3) & очи, им. (3) \\
\hline очи, им. (3) & пад, им. (3) & помало, прил. (3) & пуст, прид. (3) \\
\hline пуст, прид. (3) & реч, им. (3) & сазвежђе, им. (3) & свет, прид. (3) \\
\hline свет, прид. (3) & снага, им. (3) & снити, гл. (3) & срећа, им. (3) \\
\hline срећа, им. (3) & срна, им. (3) & страшан, прид. (3) & схватати, гл. (3) \\
\hline схватати, гл. (3) & таман, прид. (3) & тмина, им. (3) & тмуша, им. (3) \\
\hline тмуша, им. (3) & угасити (се), гл. (3) & ућутати (се), гл. (3) & цео, прид. (3) \\
\hline
\end{tabular}




\begin{tabular}{|c|c|c|c|}
\hline цео, прид. (3) & црн, прид. (3) & црта, им. (3) & чудесан, прид. (3) \\
\hline чудесан, прид. (3) & Thalassa, им. (2) & бајка, им. (2) & бесконачан, прид. (2) \\
\hline бесконачан, прид. (2) & биће, им. (2) & блажен, прид. (2) & близак, прид. (2) \\
\hline близак, прид. (2) & Буда, им. (2) & будити (се), гл. (2) & ваздушан, прид. (2) \\
\hline ваздушан, прид. (2) & ваљати, гл. (2) & васиона, им. (2) & ведар, прид. (2) \\
\hline ведар, прид. (2) & везати (се), гл. (2) & ветрић, им. (2) & вид, им. (2) \\
\hline вид, им. (2) & вити (се), гл. (2) & владати (се), гл. (2) & врвети, гл. (2) \\
\hline врвети, гл. (2) & време, им. (2) & врх, им. (2) & врхунац, им. (2) \\
\hline врхунац, им. (2) & глас, им. (2) & говор, им. (2) & гомила, им. (2) \\
\hline гомила, им. (2) & гост, им. (2) & грана, им. (2) & грех, им. (2) \\
\hline грех, им. (2) & грмље, им. (2) & губити (се), гл. (2) & густ, прид. (2) \\
\hline густ, прид. (2) & давати (се), гл. (2) & данас, прил. (2) & дах, им. (2) \\
\hline дах, им. (2) & дело, им. (2) & диван, прид. (2) & дозвати, гл. (2) \\
\hline дозвати, гл. (2) & дремати, гл. (2) & друг, им. (2) & дубина, им. (2) \\
\hline дубина, им. (2) & дубрава, им. (2) & дуг, прид. (2) & дуго, прил. (2) \\
\hline дуго, прил. (2) & жал, им. (2) & жарки, прид. (2) & жељно, прил. (2) \\
\hline жељно, прил. (2) & живљење, им. (2) & зажелети (се), гл. (2) & замрети, гл. (2) \\
\hline замрети, гл. (2) & занет, прид. (2) & застајати, гл. (2) & зауман, прид. (2) \\
\hline зауман, прид. (2) & зачути (се), гл. (2) & зашто, прил. (2) & земни, прид. (2) \\
\hline земни, прид. (2) & знан, прид. (2) & зрачан, прид. (2) & зрење, им. (2) \\
\hline зрење, им. (2) & зрети, гл. (2) & игра, им. (2) & икосаедар, им. (2) \\
\hline икосаедар, им. (2) & искон, им. (2) & истински, прид. (2) & исток, им. (2) \\
\hline исток, им. (2) & јадан, прид. (2) & јантарни, прид. (2) & јато, им. (2) \\
\hline јато, им. (2) & једино, прил. (2) & јефтин, прид. (2) & јутро, им. (2) \\
\hline јутро, им. (2) & казати, гл. (2) & каткад, прил. (2) & коначно, прил. (2) \\
\hline коначно, прил. (2) & корак, им. (2) & космос, им. (2) & кретати (се), гл. (2) \\
\hline кретати (се), гл. (2) & крив, прид. (2) & кривња, им. (2) & крилат, прид. (2) \\
\hline крилат, прид. (2) & кров, им. (2) & крој, им. (2) & круг, им. (2) \\
\hline круг, им. (2) & куд, прил. (2) & лабуд, им. (2) & лагано, прил. (2) \\
\hline лагано, прил. (2) & леп, прид. (2) & ловити, гл. (2) & лутати, гл. (2) \\
\hline
\end{tabular}




\begin{tabular}{|c|c|c|c|}
\hline лутати, гл. (2) & љескати (се), гл. (2) & магновење, им. (2) & мајушан, прид. (2) \\
\hline мајушан, прид. (2) & мали, прид. (2) & машта, им. (2) & мед, им. (2) \\
\hline мед, им. (2) & мираж, им. (2) & молити (се), гл. (2) & мрачан, прид. (2) \\
\hline мрачан, прид. (2) & мудрост, им. (2) & мука, им. (2) & мутан, прид. (2) \\
\hline мутан, прид. (2) & нада, им. (2) & народ, им. (2) & наћи (се), гл. (2) \\
\hline наћи (се), гл. (2) & негде, прил. (2) & $\begin{array}{l}\text { недостојан, прид. } \\
\text { (2) }\end{array}$ & нежан, прид. (2) \\
\hline нежан, прид. (2) & незнање, им. (2) & нејасан, прид. (2) & нем, прид. (2) \\
\hline нем, прид. (2) & немир, им. (2) & низак, прид. (2) & ноћни, прид. (2) \\
\hline ноћни, прид. (2) & обала, им. (2) & облак, им. (2) & облачан, прид. (2) \\
\hline облачан, прид. (2) & огласити (се), гл. (2) & одзвук, им. (2) & океан, им. (2) \\
\hline океан, им. (2) & окретати (се), гл. (2) & олујни, прид. (2) & опека, им. (2) \\
\hline опека, им. (2) & острво, им. (2) & отац, им. (2) & отпочети, гл. (2) \\
\hline отпочети, гл. (2) & отресати (се), гл. (2) & оштар, прид. (2) & пажљиво, прил. (2) \\
\hline пажљиво, прил. (2) & пахуља, им. (2) & петао, им. (2) & плавет, им. (2) \\
\hline плавет, им. (2) & плам, им. (2) & $\begin{array}{l}\text { планински, прид. } \\
\text { (2) }\end{array}$ & плести, гл. (2) \\
\hline плести, гл. (2) & погледати, гл. (2) & поларан, прид. (2) & полетети, гл. (2) \\
\hline полетети, гл. (2) & порив, им. (2) & постати, гл. (2) & почетак, им. (2) \\
\hline почетак, им. (2) & праведан, прид. (2) & прам, им. (2) & пратити, гл. (2) \\
\hline пратити, гл. (2) & праштати (се), гл. (2) & превој, им. (2) & прекрасан, прид. (2) \\
\hline прекрасан, прид. (2) & прећи (се), гл. (2) & привид, им. (2) & примити (се), гл. (2) \\
\hline примити (се), гл. (2) & природа, им. (2) & прозрачан, прид. (2) & прозрење, им. (2) \\
\hline прозрење, им. (2) & пун, прид. (2) & путник, им. (2) & пучина, им. (2) \\
\hline пучина, им. (2) & радост, им. (2) & раздање, им. (2) & различан, прид. (2) \\
\hline различан, прид. (2) & разнети, гл. (2) & разни, прид. (2) & расти, гл. (2) \\
\hline расти, гл. (2) & расути (се), гл. (2) & рима, им. (2) & родити (се), гл. (2) \\
\hline родити (се), гл. (2) & рука, им. (2) & саздати, гл. (2) & свемир, им. (2) \\
\hline свемир, им. (2) & светица, им. (2) & сенка, им. (2) & ситан, прид. (2) \\
\hline ситан, прид. (2) & скупити (се), гл. (2) & слика, им. (2) & слити (се), гл. (2) \\
\hline слити (се), гл. (2) & слободан, прид. (2) & смак, им. (2) & смисао, им. (2) \\
\hline
\end{tabular}


Рајна М. Драгићевић, Милош В. Утвић

\begin{tabular}{|c|c|c|c|}
\hline смисао, им. (2) & смоковац, им. (2) & снежан, прид. (2) & снен, прид. (2) \\
\hline снен, прид. (2) & спавати, гл. (2) & срећан, прид. (2) & срећно, прил. (2) \\
\hline срећно, прил. (2) & стављати, гл. (2) & стварно, прил. (2) & стерати (се), гл. (2) \\
\hline стерати (се), гл. (2) & стигнути, гл. (2) & стид, им. (2) & стих, им. (2) \\
\hline стих, им. (2) & стихнути (се), гл. (2) & стражар, им. (2) & судба, им. (2) \\
\hline судба, им. (2) & сур, прид. (2) & схватити, гл. (2) & тајна, им. (2) \\
\hline тајна, им. (2) & талас, им. (2) & творац, им. (2) & тело, им. (2) \\
\hline тело, им. (2) & терати (се), гл. (2) & трава, им. (2) & трагати, гл. (2) \\
\hline трагати, гл. (2) & трајање, им. (2) & трајати, гл. (2) & требати, гл. (2) \\
\hline требати, гл. (2) & трештати, гл. (2) & трчати, гл. (2) & туга, им. (2) \\
\hline туга, им. (2) & туђ, прид. (2) & тужан, прид. (2) & тундра, им. (2) \\
\hline тундра, им. (2) & ћутати, гл. (2) & увек, прил. (2) & узак, прид. (2) \\
\hline узак, прид. (2) & урвина, им. (2) & цар, им. (2) & цвеће, им. (2) \\
\hline цвеће, им. (2) & $\begin{array}{l}\text { час, им.у прил. } \\
\text { служби (2) }\end{array}$ & чемерно, прил. (2) & човеков, прид. (2) \\
\hline човеков, прид. (2) & чувати, гл. (2) & чудо, им. (2) & ад, им. (1) \\
\hline ад, им. (1) & Адам, им. (1) & Адамов, прид. (1) & азур, им. (1) \\
\hline азур, им. (1) & аксион, им. (1) & алас, им. (1) & алмазан, прид. (1) \\
\hline алмазан, прид. (1) & аманет, им. (1) & Андромеда, им. (1) & анђео, им. (1) \\
\hline анђео, им. (1) & антивреме, им. (1) & апел, им. (1) & арлаукати, гл. (1) \\
\hline арлаукати, гл. (1) & атом, им. (1) & Аустралија, им. (1) & бајан, прид. (1) \\
\hline бајан, прид. (1) & бајнозлатан, прид. (1) & бајован, прид. (1) & басма, им. (1) \\
\hline басма, им. (1) & бахорити, гл. (1) & бацати (се), гл. (1) & бацити, гл. (1) \\
\hline бацити, гл. (1) & башта, им. (1) & баштенски, прид. (1) & бдети, гл. (1) \\
\hline бдети, гл. (1) & бежан, прид. (1) & безбрижан, прид. (1) & безбрижје, им. (1) \\
\hline безбрижје, им. (1) & безбројан, прид. (1) & безвучје, им. (1) & безгласан, прид. (1) \\
\hline безгласан, прид. (1) & безгласје, им. (1) & безгрешје, им. (1) & бездушан, прид. (1) \\
\hline бездушан, прид. (1) & безљудан, прид. (1) & безнађе, им. (1) & беличаст, прид. (1) \\
\hline беличаст, прид. (1) & белкаст, прид. (1) & бео, прид. (1) & бесвестан, прид. (1) \\
\hline бесвестан, прид. (1) & бескрајан, прид. (1) & бесмрће, им. (1) & беснети, гл. (1) \\
\hline
\end{tabular}




\begin{tabular}{|c|c|c|c|}
\hline беснети, гл. (1) & бесплотан, прид. (1) & бесповрат, им. (1) & беспомоћан, прид. (1) \\
\hline беспомоћан, прид. (1) & беспробудан, прид. (1) & бесраман, прид. (1) & Бетелгеза, им. (1) \\
\hline Бетелгеза, им. (1) & бешуман, прид. (1) & библијски, прид. (1) & бивање, им. (1) \\
\hline бивање, им. (1) & бивати, гл. (1) & бивство, им. (1) & биглисан, прид. (1) \\
\hline биглисан, прид. (1) & било, им. (1) & биљур, им. (1) & бион, им. (1) \\
\hline бион, им. (1) & бирати, гл. (1) & бићенце, им. (1) & благ, прид. (1) \\
\hline благ, прид. (1) & блед, прид. (1) & бледило, им. (1) & бледожут, прид. (1) \\
\hline бледожут, прид. (1) & блештати, гл. (1) & ближити (се), гл. (1) & близу, прил. (1) \\
\hline близу, прил. (1) & блискати (се), гл. (1) & блистати, гл. (1) & блудети, гл. (1) \\
\hline блудети, гл. (1) & бљут, им. (1) & боја, им. (1) & бол, им. (1) \\
\hline бол, им. (1) & бор, им. (1) & бранити (се), гл. (1) & браћа, им. (1) \\
\hline браћа, им. (1) & брег, им. (1) & брежје, им. (1) & бреме, им. (1) \\
\hline бреме, им. (1) & брз, прид. (1) & брзина, им. (1) & брзо, прил. (1) \\
\hline брзо, прил. (1) & бридети, гл. (1) & брисати, гл. (1) & број, им. (1) \\
\hline број, им. (1) & брујати, гл. (1) & бубица, им. (1) & бубрети, гл. (1) \\
\hline бубрети, гл. (1) & будућност, им. (1) & буј, им. (1) & буљук, им. (1) \\
\hline буљук, им. (1) & бура, им. (1) & бучати, гл. (1) & ваздух, им. (1) \\
\hline ваздух, им. (1) & валовље, им. (1) & $\begin{array}{l}\text { ванразумски, прид. } \\
\text { (1) }\end{array}$ & вапај, им. (1) \\
\hline вапај, им. (1) & вапити, гл. (1) & варан, прид. (1) & варничав, прид. (1) \\
\hline варничав, прид. (1) & Василида, им. (1) & васколик, прид. (1) & $\begin{array}{l}\text { ватроносан, прид. } \\
\text { (1) }\end{array}$ \\
\hline ватроносан, прид. (1) & ведро, прил. (1) & вејати, гл. (1) & венути, гл. (1) \\
\hline венути, гл. (1) & вео, им. (1) & веран, прид. (1) & верност, им. (1) \\
\hline верност, им. (1) & веровање, им. (1) & веслати, гл. (1) & веслач, им. (1) \\
\hline веслач, им. (1) & весник, им. (1) & ветрен, прид. (1) & ветрењаст, прид. (1) \\
\hline ветрењаст, прид. (1) & ветрокрил, прид. (1) & вечан, прид. (1) & вечерњи, прид. (1) \\
\hline вечерњи, прид. (1) & вечит, прид. (1) & вечно, прил. (1) & вечност, им. (1) \\
\hline вечност, им. (1) & виђење, им. (1) & визија, им. (1) & вијати, гл. (1) \\
\hline вијати, гл. (1) & вијоврат, прид. (1) & вијоран, прид. (1) & вилински, прид. (1) \\
\hline вилински, прид. (1) & вилица, им. (1) & виме, им. (1) & винути (се), гл. (1) \\
\hline
\end{tabular}




\begin{tabular}{|c|c|c|c|}
\hline винути (се), гл. (1) & винце, им. (1) & вирити, гл. (1) & вис, им. (1) \\
\hline вис, им. (1) & висина, им. (1) & вит, прид. (1) & виткаст, прид. (1) \\
\hline виткаст, прид. (1) & виткост, им. (1) & вишњи, прид. (1) & влас, им. (1) \\
\hline влас, им. (1) & властво, им. (1) & воља, им. (1) & врана, им. (1) \\
\hline врана, им. (1) & врат, им. (1) & врашки, прид. (1) & вргнути, гл. (1) \\
\hline вргнути, гл. (1) & вредан, прид. (1) & врење, им. (1) & вриштав, прид. (1) \\
\hline вриштав, прид. (1) & врлет, им. (1) & врли, прид. (1) & вртложење, им. (1) \\
\hline вртложење, им. (1) & врцати, гл. (1) & врцкати, гл. (1) & вучји, прид. (1) \\
\hline вучји, прид. (1) & галеб, им. (1) & гар, им. (1) & гасити, гл. (1) \\
\hline гасити, гл. (1) & генеза, им. (1) & гибак, прид. (1) & гибање, им. (1) \\
\hline гибање, им. (1) & гладити, гл. (1) & гласити, гл. (1) & гневан, прид. (1) \\
\hline гневан, прид. (1) & гностичар, им. (1) & гњилина, им. (1) & го, прид. (1) \\
\hline го, прид. (1) & говорити, гл. (1) & гозба, им. (1) & голобрад, прид. (1) \\
\hline голобрад, прид. (1) & гонити (се), гл. (1) & горд, прид. (1) & гордити (се), гл. (1) \\
\hline гордити (се), гл. (1) & горе, прил. (1) & горети, гл. (1) & горући, прид. (1) \\
\hline горући, прид. (1) & господњи, прид. (1) & Господов, прид. (1) & град, им. (1) \\
\hline град, им. (1) & градиво, им. (1) & гранитан, прид. (1) & грање, им. (1) \\
\hline грање, им. (1) & грдан, прид. (1) & гребен, им. (1) & грешан, прид. (1) \\
\hline грешан, прид. (1) & грешити, гл. (1) & грешком, прил. (1) & грешно, прил. (1) \\
\hline грешно, прил. (1) & грич, им. (1) & грло, им. (1) & грмети, гл. (1) \\
\hline грмети, гл. (1) & гроб, им. (1) & гроза, им. (1) & громада, им. (1) \\
\hline громада, им. (1) & громорити, гл. (1) & громотати, гл. (1) & груди, им. (1) \\
\hline груди, им. (1) & грунути, гл. (1) & грч, им. (1) & гуд, им. (1) \\
\hline гуд, им. (1) & гудура, им. (1) & гулити (се), гл. (1) & гурати (се), гл. (1) \\
\hline гурати (се), гл. (1) & густо, прил. (1) & гушљив, прид. (1) & давнашњи, прид. (1) \\
\hline давнашњи, прид. (1) & давно, прил. (1) & даворити (се), гл. (1) & даљина, им. (1) \\
\hline даљина, им. (1) & даљнослутан, прид. (1) & дамар, им. (1) & двојан, прид. (1) \\
\hline двојан, прид. (1) & двојник, им. (1) & двопек, им. (1) & дворјанин, им. (1) \\
\hline дворјанин, им. (1) & дебло, им. (1) & делање, им. (1) & делити, гл. (1) \\
\hline делити, гл. (1) & делфин, им. (1) & дерати (се), гл. (1) & детињи, прид. (1) \\
\hline
\end{tabular}




\begin{tabular}{|c|c|c|c|}
\hline детињи, прид. (1) & детињство, им. (1) & диваљ, прид. (1) & дивота, им. (1) \\
\hline дивота, им. (1) & дигнут, прид. (1) & дигнути (ce), гл. (1) & дим, им. (1) \\
\hline дим, им. (1) & диман, прид. (1) & дисати, гл. (1) & дифузан, прид. (1) \\
\hline дифузан, прид. (1) & добит, им. (1) & добро, прил. (1) & довикнути, гл. (1) \\
\hline довикнути, гл. (1) & довршеност, им. (1) & додекаедар, им. (1) & $\begin{array}{l}\text { додиривати (ce), } \\
\text { гл. (1) }\end{array}$ \\
\hline $\begin{array}{l}\text { додиривати (се), } \\
\text { гл. (1) }\end{array}$ & дозволити, гл. (1) & дозив, им. (1) & доказ, им. (1) \\
\hline доказ, им. (1) & доле, прил. (1) & дом, им. (1) & доста, прил. (1) \\
\hline доста, прил. (1) & достигнути, гл. (1) & $\begin{array}{l}\text { достојанствен, } \\
\text { прид. (1) }\end{array}$ & дотакнути (се), гл. (1) \\
\hline $\begin{array}{l}\text { дотакнути (се), } \\
\text { гл. (1) }\end{array}$ & $\begin{array}{l}\text { дотеривати (се), } \\
\text { гл. (1) }\end{array}$ & доћи, гл. (1) & дочекати, гл. (1) \\
\hline дочекати, гл. (1) & драгост, им. (1) & драгуљ, им. (1) & драча, им. (1) \\
\hline драча, им. (1) & држати, гл. (1) & друга, им. (1) & дрхтав, прид. (1) \\
\hline дрхтав, прид. (1) & дрхтај, им. (1) & дуга, им. (1) & думан, им. (1) \\
\hline думан, им. (1) & думача, им. (1) & дунути, гл. (1) & ђубре, им. (1) \\
\hline ђубре, им. (1) & ђускати, гл. (1) & електрончић, им. (1) & еон, им. (1) \\
\hline еон, им. (1) & жагор, им. (1) & жад, им. (1) & жалан, прид. (1) \\
\hline жалан, прид. (1) & жалити (се), гл. (1) & жаморан, прид. (1) & жао, прил. (1) \\
\hline жао, прил. (1) & жар, им. (1) & жар-птица, им. (1) & ждребад, им. (1) \\
\hline ждребад, им. (1) & жедан, прид. (1) & желатин, им. (1) & желатиноза, им. (1) \\
\hline желатиноза, им. (1) & жеља, им. (1) & жељан, прид. (1) & жељен, прид. (1) \\
\hline жељен, прид. (1) & жив, прид. (1) & жидак, прид. (1) & жижа, им. (1) \\
\hline жижа, им. (1) & жиће, им. (1) & жмуркати, им. (1) & жртва, им. (1) \\
\hline жртва, им. (1) & жубор, им. (1) & жуд, им. (1) & жут, прид. (1) \\
\hline жут, прид. (1) & забачен, прид. (1) & забит, прид. (1) & завет, им. (1) \\
\hline завет, им. (1) & завладати, гл. (1) & заводити, гл. (1) & заволети (се), гл. (1) \\
\hline заволети (се), гл. (1) & завртети (се), гл. (1) & загледан, прид. (1) & заглушан, прид. (1) \\
\hline заглушан, прид. (1) & задан, прид. (1) & задатак, им. (1) & закорачивати, гл. (1) \\
\hline закорачивати, гл. (1) & $\begin{array}{l}\text { закривати (се), } \\
\text { гл. (1) }\end{array}$ & залазак, им. (1) & залутао, прид. (1) \\
\hline
\end{tabular}




\begin{tabular}{|c|c|c|c|}
\hline залутао, прид. (1) & залутати, гл. (1) & заман, прил. (1) & замах, им. (1) \\
\hline замах, им. (1) & $\begin{array}{l}\text { заменити (се), гл. } \\
\text { (1) }\end{array}$ & замишљен, прид. (1) & замолити, гл. (1) \\
\hline замолити, гл. (1) & занавек, прил. (1) & занимљиво, прил. (1) & заогрнут, прид. (1) \\
\hline заогрнут, прид. (1) & запалити (се), гл. (1) & запоноћје, им. (1) & заправо, прил. (1) \\
\hline заправо, прил. (1) & запретен, прид. (1) & заселак, им. (1) & заслужен, прид. (1) \\
\hline заслужен, прид. (1) & застао, прид. (1) & засузити (се), гл. (1) & зато, прил. (1) \\
\hline зато, прил. (1) & затурен, прид. (1) & заћутати, гл. (1) & захвално, прил. (1) \\
\hline захвално, прил. (1) & захват, им. (1) & захватити, гл. (1) & зачети (се), гл. (1) \\
\hline зачети (се), гл. (1) & зачеће, им. (1) & звати (се), гл. (1) & звездица, им. (1) \\
\hline звездица, им. (1) & звон, им. (1) & звонити, гл. (1) & звуковље, им. (1) \\
\hline звуковље, им. (1) & звучати, гл. (1) & здање, им. (1) & здравље, им. (1) \\
\hline здравље, им. (1) & зелен, прид. (1) & зеленкаст, прид. (1) & земаљски, прид. (1) \\
\hline земаљски, прид. (1) & зечић, им. (1) & златан, прид. (1) & злато, им. (1) \\
\hline злато, им. (1) & злаћан, прид. (1) & злосрећан, прид. (1) & змај, им. (1) \\
\hline змај, им. (1) & змија, им. (1) & знатижеља, им. (1) & зовнути, гл. (1) \\
\hline зовнути, гл. (1) & зрелост, им. (1) & зујати, гл. (1) & зурити, гл. (1) \\
\hline зурити, гл. (1) & ивица, им. (1) & идеал, им. (1) & избегнути, гл. (1) \\
\hline избегнути, гл. (1) & избројати, гл. (1) & извиђати, гл. (1) & извијати (се), гл. (1) \\
\hline извијати (се), гл. (1) & изгледати, гл. (1) & изгледнути, гл. (1) & изгнан, прид. (1) \\
\hline изгнан, прид. (1) & изградити, гл. (1) & изгубљен, прид. (1) & издашан, прид. (1) \\
\hline издашан, прид. (1) & излишан, прид. (1) & изразити (се), гл. (1) & изрод, им. (1) \\
\hline изрод, им. (1) & изумљење, им. (1) & исказати (се), гл. (1) & искати, гл. (1) \\
\hline искати, гл. (1) & искежен, прид. (1) & искрав, прид. (1) & искупити (се), гл. (1) \\
\hline искупити (се), гл. (1) & исписати (се), гл. (1) & испотаја, им. (1) & испрепадан, прид. (1) \\
\hline испрепадан, прид. (1) & $\begin{array}{l}\text { испуњавати (се), } \\
\text { гл. (1) }\end{array}$ & истинитост, им. (1) & истински, прил. (1) \\
\hline истински, прил. (1) & источни, прид. (1) & источник, им. (1) & ишчезнути, гл. (1) \\
\hline ишчезнути, гл. (1) & јава, им. (1) & јад, им. (1) & јажа, им. (1) \\
\hline јажа, им. (1) & јазбина, им. (1) & јак, прид. (1) & јарак, им. (1) \\
\hline јарак, им. (1) & јарни, прид. (1) & једаред, прил. (1) & једва, прил. (1) \\
\hline
\end{tabular}




\begin{tabular}{|c|c|c|c|}
\hline једва, прил. (1) & једнако, прил. (1) & једро, им. (1) & јесењи, прид. (1) \\
\hline јесењи, прид. (1) & југ, им. (1) & јужни, прид. (1) & јунак, им. (1) \\
\hline јунак, им. (1) & јурити, гл. (1) & казивање, им. (1) & кам, им. (1) \\
\hline кам, им. (1) & камен, им. (1) & кап, им. (1) & капуља, им. (1) \\
\hline капуља, им. (1) & капут, им. (1) & карбидни, прид. (1) & каткада, прил. (1) \\
\hline каткада, прил. (1) & кедар, им. (1) & кече, им. (1) & кикот, им. (1) \\
\hline кикот, им. (1) & кинђурни, прид. (1) & киша, им. (1) & кишни, прид. (1) \\
\hline кишни, прид. (1) & клепало, им. (1) & клизнути (се), гл. (1) & кликтав, прид. (1) \\
\hline кликтав, прид. (1) & кликтати, гл. (1) & клонути, гл. (1) & клупа, им. (1) \\
\hline клупа, им. (1) & кобан, прид. (1) & кожица, им. (1) & кола, им. (1) \\
\hline кола, им. (1) & колиба, им. (1) & колико, прил. (1) & количина, им. (1) \\
\hline количина, им. (1) & комета, им. (1) & коначан, прид. (1) & кончина, им. (1) \\
\hline кончина, им. (1) & коњ, им. (1) & коњски, прид. (1) & копито, им. (1) \\
\hline копито, им. (1) & копнети, гл. (1) & корење, им. (1) & коровски, прид. (1) \\
\hline коровски, прид. (1) & кос, прид. (1) & коса, им. (1) & космички, прид. (1) \\
\hline космички, прид. (1) & космогонија, им. (1) & $\begin{array}{l}\text { космозвучан, прид. } \\
\text { (1) }\end{array}$ & кошута, им. (1) \\
\hline кошута, им. (1) & красити, гл. (1) & крвити (се), гл. (1) & крвник, им. (1) \\
\hline крвник, им. (1) & креснути, гл. (1) & кретња, им. (1) & крити (се), гл. (1) \\
\hline крити (се), гл. (1) & кричати, гл. (1) & кришом, прил. (1) & крошња, им. (1) \\
\hline крошња, им. (1) & крстити (се), гл. (1) & кружан, прид. (1) & круна, им. (1) \\
\hline круна, им. (1) & крунаст, прид. (1) & крхутак, им. (1) & крш, им. (1) \\
\hline крш, им. (1) & купити (се), гл. (1) & кут, им. (1) & кућни, прид. (1) \\
\hline кућни, прид. (1) & Лав, им. (1) & лавина, им. (1) & лађа, им. (1) \\
\hline лађа, им. (1) & лажан, прид. (1) & лампа, им. (1) & лампион, им. (1) \\
\hline лампион, им. (1) & ланад, им. (1) & ласта, им. (1) & лат, им. (1) \\
\hline лат, им. (1) & лахор, им. (1) & лахорити, гл. (1) & лебдети, гл. (1) \\
\hline лебдети, гл. (1) & левитирати, гл. (1) & легенда, им. (1) & легло, им. (1) \\
\hline легло, им. (1) & ледан, прид. (1) & леја, им. (1) & лепеза, им. (1) \\
\hline лепеза, им. (1) & лепо, прил. (1) & лето, им. (1) & лик, им. (1) \\
\hline
\end{tabular}


Рајна М. Драгићевић, Милош В. Утвић

\begin{tabular}{|c|c|c|c|}
\hline лик, им. (1) & лира, им. (1) & лиснат, прид. (1) & литица, им. (1) \\
\hline литица, им. (1) & лице, им. (1) & лишће, им. (1) & ловац, им. (1) \\
\hline ловац, им. (1) & лог, им. (1) & лођа, им. (1) & лоза, им. (1) \\
\hline лоза, им. (1) & луд, прид. (1) & $\begin{array}{l}\text { луминисцирати, } \\
\text { гл. (1) }\end{array}$ & луна, им. (1) \\
\hline луна, им. (1) & луч, им. (1) & љубимац, им. (1) & $\begin{array}{l}\text { љубопитство, им. } \\
\text { (1) }\end{array}$ \\
\hline љубопитство, им. (1) & љут, прид. (1) & магично, прил. (1) & маглен, прид. (1) \\
\hline маглен, прид. (1) & маглина, им. (1) & магнолија, им. (1) & мајстор, им. (1) \\
\hline мајстор, им. (1) & макнут, прид. (1) & маман, прид. (1) & мана, им. (1) \\
\hline мана, им. (1) & маска, им. (1) & мастиљав, прид. (1) & материја, им. (1) \\
\hline материја, им. (1) & махати, гл. (1) & мачка, им. (1) & маштати, гл. (1) \\
\hline маштати, гл. (1) & међа, им. (1) & межурати (се), гл. (1) & мек, прид. (1) \\
\hline мек, прид. (1) & мелодија, им. (1) & мемла, им. (1) & мена, им. (1) \\
\hline мена, им. (1) & мерни, прид. (1) & месечар, им. (1) & Месечев, прид. (1) \\
\hline Месечев, прид. (1) & мета, им. (1) & метак, им. (1) & метеж, им. (1) \\
\hline метеж, им. (1) & мећава, им. (1) & милошта, им. (1) & миран, прид. (1) \\
\hline миран, прид. (1) & мислити, гл. (1) & мистерија, им. (1) & мистичан, прид. (1) \\
\hline мистичан, прид. (1) & млад, прид. (1) & младост, им. (1) & млечан, прид. (1) \\
\hline млечан, прид. (1) & многи, прид. (1) & мноштво, им. (1) & модрина, им. (1) \\
\hline модрина, им. (1) & моржев, прид. (1) & морски, прид. (1) & мотрити (се), гл. (1) \\
\hline мотрити (ce), гл. (1) & моћан, прид. (1) & Моцарт, им. (1) & мразан, прид. (1) \\
\hline мразан, прид. (1) & мрежа, им. (1) & мрк, прид. (1) & мркли, прид. (1) \\
\hline мркли, прид. (1) & мрклина, им. (1) & мртав, прид. (1) & муљ, им. (1) \\
\hline муљ, им. (1) & муња, им. (1) & муња-злица, им. (1) & мусти, гл. (1) \\
\hline мусти, гл. (1) & мутација, им. (1) & мутнина, им. (1) & мушица, им. (1) \\
\hline мушица, им. (1) & нагло, прил. (1) & нагоре, прил. (1) & $\begin{array}{l}\text { надмучити (ce), } \\
\text { гл. (1) }\end{array}$ \\
\hline $\begin{array}{l}\text { надмучити (ce), } \\
\text { гл. (1) }\end{array}$ & наднет, прид. (1) & надоблачан, прид. (1) & назад, прил. (1) \\
\hline назад, прил. (1) & назирати, гл. (1) & назначити, гл. (1) & назрети, гл. (1) \\
\hline
\end{tabular}




\begin{tabular}{|c|c|c|c|}
\hline назрети, гл. (1) & $\begin{array}{l}\text { наједанпут, прил. } \\
\text { (1) }\end{array}$ & наједном, прил. (1) & налет, им. (1) \\
\hline налет, им. (1) & налити (се), гл. (1) & намена, им. (1) & намигнути, гл. (1) \\
\hline намигнути, гл. (1) & напев, им. (1) & $\begin{array}{l}\text { напрегнути (ce), } \\
\text { гл. (1) }\end{array}$ & напред, прил. (1) \\
\hline напред, прил. (1) & насладно, прил. (1) & $\begin{array}{l}\text { наслонити (се), } \\
\text { гл. (1) }\end{array}$ & натегнути, гл. (1) \\
\hline натегнути, гл. (1) & натраг, прил. (1) & натчујни, прид. (1) & натчулни, прид. (1) \\
\hline натчулни, прид. (1) & наум, им. (1) & начинити, гл. (1) & небесан, прид. (1) \\
\hline небесан, прид. (1) & небит, им. (1) & небиће, им. (1) & небројен, прид. (1) \\
\hline небројен, прид. (1) & невидљив, прид. (1) & невид-путања, им. (1) & невољно, прил. (1) \\
\hline невољно, прил. (1) & негдашњи, прид. (1) & негрејан, прид. (1) & недирнут, прид. (1) \\
\hline недирнут, прид. (1) & недосежан, прид. (1) & недоумица, им. (1) & недра, им. (1) \\
\hline недра, им. (1) & нежив, прид. (1) & нежно, прил. (1) & нежност, им. (1) \\
\hline нежност, им. (1) & незамислив, прид. (1) & незгодно, прил. (1) & $\begin{array}{l}\text { неземаљски, прид. } \\
\text { (1) }\end{array}$ \\
\hline неземаљски, прид. (1) & неизбројан, прид. (1) & неизбројив, прид. (1) & неиследан, прид. (1) \\
\hline неиследан, прид. (1) & неколико, прил. (1) & неломив, прид. (1) & немерљив, прид. (1) \\
\hline немерљив, прид. (1) & немерни, прид. (1) & немоћан, прид. (1) & $\begin{array}{l}\text { неовдашњи, прид. } \\
\text { (1) }\end{array}$ \\
\hline неовдашњи, прид. (1) & неохватан, прид. (1) & непознат, прид. (1) & непојмљив, прид. (1) \\
\hline непојмљив, прид. (1) & непојмљиво, прил. (1) & непослушан, прид. (1) & непребројан, прид. (1) \\
\hline непребројан, прид. (1) & непробојан, прид. (1) & непрозиран, прид. (1) & неразорив, прид. (1) \\
\hline неразорив, прид. (1) & несвагдањи, прид. (1) & нескврнут, прид. (1) & нестати, гл. (1) \\
\hline нестати, гл. (1) & несувисли, прид. (1) & нетражен, прид. (1) & неутрино, им. (1) \\
\hline неутрино, им. (1) & неухватљив, прид. (1) & нирвана, им. (1) & ниско, прил. (1) \\
\hline ниско, прил. (1) & нит, им. (1) & ништаван, прид. (1) & нога, им. (1) \\
\hline нога, им. (1) & ножица, им. (1) & ношен, прид. (1) & њихати (се), гл. (1) \\
\hline њихати (се), гл. (1) & обасјати, гл. (1) & обзор, им. (1) & облачак, им. (1) \\
\hline облачак, им. (1) & обрис, им. (1) & овако, прил. (1) & овити (се), гл. (1) \\
\hline овити (се), гл. (1) & огањ, им. (1) & ограшје, им. (1) & огрнут, прид. (1) \\
\hline огрнут, прид. (1) & ода, им. (1) & одавати, гл. (1) & одавде, прил. (1) \\
\hline
\end{tabular}


Рајна М. Драгићевић, Милош В. Утвић

\begin{tabular}{|c|c|c|c|}
\hline одавде, прил. (1) & одавно, прил. (1) & одан, прид. (1) & одводити, гл. (1) \\
\hline одводити, гл. (1) & одговор, им. (1) & одевен, прид. (1) & одјек, им. (1) \\
\hline одјек, им. (1) & однекуд, прил. (1) & одозго, прил. (1) & одсад, прил. (1) \\
\hline одсад, прил. (1) & одурје, им. (1) & озареност, им. (1) & озго, прил. (1) \\
\hline озго, прил. (1) & ознање, им. (1) & ојађен, прид. (1) & около, прил. (1) \\
\hline около, прил. (1) & окрепан, прид. (1) & окружен, прид. (1) & олеандар, им. (1) \\
\hline олеандар, им. (1) & олимпијски, прид. (1) & олук, им. (1) & онкрај, прил. (1) \\
\hline онкрај, прил. (1) & онуда, прил. (1) & опазити, гл. (1) & опак, прид. (1) \\
\hline опак, прид. (1) & опрезан, прид. (1) & опрезно, прил. (1) & опробати (се), гл. (1) \\
\hline опробати (се), гл. (1) & опростити, гл. (1) & опхрван, прид. (1) & орао, им. (1) \\
\hline орао, им. (1) & Орион, им. (1) & освежен, прид. (1) & $\begin{array}{l}\text { осветљавати (се), } \\
\text { гл. (1) }\end{array}$ \\
\hline $\begin{array}{l}\text { осветљавати (се), } \\
\text { гл. (1) }\end{array}$ & освит, им. (1) & осиротети, гл. (1) & осмејак, им. (1) \\
\hline осмејак, им. (1) & осмех, им. (1) & остатак, им. (1) & отајствен, прид. (1) \\
\hline отајствен, прид. (1) & отворити (се), гл. (1) & отисак, им. (1) & откако, прил. (1) \\
\hline откако, прил. (1) & откуцан, прид. (1) & $\begin{array}{l}\text { отргнути (се), гл. } \\
\text { (1) }\end{array}$ & охолити (се), гл. (1) \\
\hline охолити (се), гл. (1) & очезнуће, им. (1) & очински, прид. (1) & падати, гл. (1) \\
\hline падати, гл. (1) & пажња, им. (1) & палица, им. (1) & паљба, им. (1) \\
\hline паљба, им. (1) & памтити, гл. (1) & папак, им. (1) & парк, им. (1) \\
\hline парк, им. (1) & парче, им. (1) & пасти, гл. (1) & пасторак, им. (1) \\
\hline пасторак, им. (1) & паучица, им. (1) & певан, прид. (1) & певати, гл. (1) \\
\hline певати, гл. (1) & Пегаз, им. (1) & пелуд, им. (1) & пена, им. (1) \\
\hline пена, им. (1) & $\begin{array}{l}\text { пенушати (ce), } \\
\text { гл. (1) }\end{array}$ & петлов, прид. (1) & печурка, им. (1) \\
\hline печурка, им. (1) & печуркин, прид. (1) & пиктија, им. (1) & пинија, им. (1) \\
\hline пинија, им. (1) & писмо, им. (1) & питати, гл. (1) & пиће, им. (1) \\
\hline пиће, им. (1) & плавети, гл. (1) & $\begin{array}{l}\text { пламен-наранџа, } \\
\text { им. (1) }\end{array}$ & пламити (се), гл. (1) \\
\hline пламити (се), гл. (1) & пламсај, им. (1) & планина, им. (1) & плах, прид. (1) \\
\hline
\end{tabular}




\begin{tabular}{|c|c|c|c|}
\hline плах, прид. (1) & $\begin{array}{l}\text { плашити (се), гл. } \\
\text { (1) }\end{array}$ & плејада, им. (1) & плес, им. (1) \\
\hline плес, им. (1) & плот, им. (1) & пљескати, гл. (1) & пљускање, им. (1) \\
\hline пљускање, им. (1) & пљуштати, гл. (1) & повити, гл. (1) & погодити (се), гл. (1) \\
\hline погодити (се), гл. (1) & погубан, прид. (1) & подавити, гл. (1) & поделити, гл. (1) \\
\hline поделити, гл. (1) & подмазати, гл. (1) & подне, им. (1) & поднебески, прид. (1) \\
\hline поднебески, прид. (1) & пожелети, гл. (1) & појање, им. (1) & покуљати, гл. (1) \\
\hline покуљати, гл. (1) & пола, прил. (1) & полегнути, гл. (1) & положај, им. (1) \\
\hline положај, им. (1) & пољски, прид. (1) & помисао, им. (1) & помол, им. (1) \\
\hline помол, им. (1) & понекад, прил. (1) & понети, гл. (1) & понизан, прид. (1) \\
\hline понизан, прид. (1) & $\begin{array}{l}\text { поновити (се), гл. } \\
\text { (1) }\end{array}$ & понор, им. (1) & понос, им. (1) \\
\hline понос, им. (1) & попао, прид. (1) & $\begin{array}{l}\text { посвемашњи, прид. } \\
\text { (1) }\end{array}$ & поскочити, гл. (1) \\
\hline поскочити, гл. (1) & после, прил. (1) & послушан, прид. (1) & послушати, гл. (1) \\
\hline послушати, гл. (1) & посматрати, гл. (1) & постање, им. (1) & постиђен, прид. (1) \\
\hline постиђен, прид. (1) & постојање, им. (1) & постојати, гл. (1) & посустати, гл. (1) \\
\hline посустати, гл. (1) & посути (се), гл. (1) & потакнути, гл. (1) & потпалити, гл. (1) \\
\hline потпалити, гл. (1) & поћи, гл. (1) & почесто, прил. (1) & прав, прид. (1) \\
\hline прав, прид. (1) & правда, им. (1) & $\begin{array}{l}\text { правдати (се), гл. } \\
\text { (1) }\end{array}$ & праведник, им. (1) \\
\hline праведник, им. (1) & правити (се), гл. (1) & право, прил. (1) & правреме, им. (1) \\
\hline правреме, им. (1) & $\begin{array}{l}\text { праисконски, прид. } \\
\text { (1) }\end{array}$ & прапрви, прид. (1) & праскозорје, им. (1) \\
\hline праскозорје, им. (1) & праћка, им. (1) & прах, им. (1) & првенац, им. (1) \\
\hline првенац, им. (1) & пре, прил. (1) & пребирати, гл. (1) & прегнуће, им. (1) \\
\hline прегнуће, им. (1) & прегршт, им. (1) & предати (се), гл. (1) & $\begin{array}{l}\text { предбивствовати, } \\
\text { гл. (1) }\end{array}$ \\
\hline $\begin{array}{l}\text { предбивствовати, } \\
\text { гл. (1) }\end{array}$ & $\begin{array}{l}\text { предвечан, прид. } \\
\text { (1) }\end{array}$ & предео, им. (1) & $\begin{array}{l}\text { предстворен, прид. } \\
\text { (1) }\end{array}$ \\
\hline предстворен, прид. (1) & $\begin{array}{l}\text { прекоморски, прид. } \\
\text { (1) }\end{array}$ & прекрити (се), гл. (1) & прелеп, прид. (1) \\
\hline прелеп, прид. (1) & преломити, гл. (1) & премноги, прид. (1) & престати, гл. (1) \\
\hline
\end{tabular}


Рајна М. Драгићевић, Милош В. Утвић

\begin{tabular}{|c|c|c|c|}
\hline престати, гл. (1) & претакати, гл. (1) & прецесија, им. (1) & прече, прил. (1) \\
\hline прече, прил. (1) & приземљуша, им. (1) & призивати, гл. (1) & признавати, гл. (1) \\
\hline признавати, гл. (1) & пријатељица, им. (1) & примећивати, гл. (1) & приправан, прид. (1) \\
\hline приправан, прид. (1) & присен, им. (1) & пристизати, гл. (1) & прича, им. (1) \\
\hline прича, им. (1) & причати, гл. (1) & $\begin{array}{l}\text { причињати (се), } \\
\text { гл. (1) }\end{array}$ & пробити (се), гл. (1) \\
\hline пробити (се), гл. (1) & пробни, прид. (1) & провалија, им. (1) & провидан, прид. (1) \\
\hline провидан, прид. (1) & проживети, гл. (1) & $\begin{array}{l}\text { прожимати (се), } \\
\text { гл. (1) }\end{array}$ & прозбор, им. (1) \\
\hline прозбор, им. (1) & прозборити, гл. (1) & прозор, им. (1) & промакнути, гл. (1) \\
\hline промакнути, гл. (1) & проминути, гл. (1) & просинути, гл. (1) & простор, им. (1) \\
\hline простор, им. (1) & протрчати, гл. (1) & проћи, гл. (1) & $\begin{array}{l}\text { проходити (се), } \\
\text { гл. (1) }\end{array}$ \\
\hline $\begin{array}{l}\text { проходити (се), } \\
\text { гл. (1) }\end{array}$ & прпошан, прид. (1) & прст, им. (1) & птић, им. (1) \\
\hline птић, им. (1) & пужевљев, прид. (1) & пунити, гл. (1) & равнати (се), гл. (1) \\
\hline равнати (се), гл. (1) & радознао, прид. (1) & радосно, прил. (1) & разапет, прид. (1) \\
\hline разапет, прид. (1) & разбуктао, прид. (1) & развала, им. (1) & развејан, прид. (1) \\
\hline развејан, прид. (1) & разврнути, гл. (1) & $\begin{array}{l}\text { раздањивати (се), } \\
\text { гл. (1) }\end{array}$ & раззвежђе, им. (1) \\
\hline раззвежђе, им. (1) & разигран, прид. (1) & разлистан, прид. (1) & разлог, им. (1) \\
\hline разлог, им. (1) & размишљати, гл. (1) & разноок, прид. (1) & разносити, гл. (1) \\
\hline разносити, гл. (1) & разум, им. (1) & paj, им. (1) & ран, прид. (1) \\
\hline ран, прид. (1) & расвиће, им. (1) & раскошно, прил. (1) & $\begin{array}{l}\text { раскрилити (се), } \\
\text { гл. (1) }\end{array}$ \\
\hline $\begin{array}{l}\text { раскрилити (се), } \\
\text { гл. (1) }\end{array}$ & распознавати, гл. (1) & распрсао, прид. (1) & распрснуће, им. (1) \\
\hline распрснуће, им. (1) & растати (се), гл. (1) & растурен, прид. (1) & расудност, им. (1) \\
\hline расудност, им. (1) & расшифрати, гл. (1) & ратнички, прид. (1) & Рафаел, им. (1) \\
\hline Рафаел, им. (1) & редом, прил. (1) & река, им. (1) & реп, им. (1) \\
\hline реп, им. (1) & речни, прид. (1) & решити (се), гл. (1) & риба, им. (1) \\
\hline риба, им. (1) & Ригел, им. (1) & ригнути, гл. (1) & ридати, гл. (1) \\
\hline ридати, гл. (1) & риза, им. (1) & роб, им. (1) & Робинзон, им. (1) \\
\hline
\end{tabular}




\begin{tabular}{|c|c|c|c|}
\hline Робинзон, им. (1) & $\begin{array}{l}\text { рогушити (се), } \\
\text { гл. (1) }\end{array}$ & род, им. (1) & родни, прид. (1) \\
\hline родни, прид. (1) & poj, им. (1) & роса, им. (1) & рт, им. (1) \\
\hline рт, им. (1) & руб, им. (1) & рудити, гл. (1) & руина, им. (1) \\
\hline руина, им. (1) & руј, им. (1) & рушан, прид. (1) & сабластан, прид. (1) \\
\hline сабластан, прид. (1) & сабља-зуб, им. (1) & сабрат, им. (1) & сабрати (се), гл. (1) \\
\hline сабрати (се), гл. (1) & савет, им. (1) & сажети, гл. (1) & сажећи, гл. (1) \\
\hline сажећи, гл. (1) & сазвати, гл. (1) & саздан, прид. (1) & сазнат, прид. (1) \\
\hline сазнат, прид. (1) & сазнати, гл. (1) & салаш, им. (1) & салинац, им. (1) \\
\hline салинац, им. (1) & сало, им. (1) & самотан, прид. (1) & $\begin{array}{l}\text { самотнички, прид. } \\
\text { (1) }\end{array}$ \\
\hline самотнички, прид. (1) & самоћа, им. (1) & сања, им. (1) & сањан, прид. (1) \\
\hline сањан, прид. (1) & сањарење, им. (1) & сањарити, гл. (1) & свагда, прил. (1) \\
\hline свагда, прил. (1) & свемирски, прид. (1) & свенути, гл. (1) & $\begin{array}{l}\text { сверовати (се), гл. } \\
\text { (1) }\end{array}$ \\
\hline сверовати (се), гл. (1) & светац, им. (1) & светлети, гл. (1) & светлина, им. (1) \\
\hline светлина, им. (1) & светло, им. (1) & $\begin{array}{l}\text { светлоплав, прид. } \\
\text { (1) }\end{array}$ & светлост, им. (1) \\
\hline светлост, им. (1) & свечан, прид. (1) & $\begin{array}{l}\text { свикавати (се), } \\
\text { гл. (1) }\end{array}$ & свирати, гл. (1) \\
\hline свирати, гл. (1) & свитати, гл. (1) & свладати, гл. (1) & свршен, прид. (1) \\
\hline свршен, прид. (1) & свршетак, им. (1) & севнути, гл. (1) & сегнути, гл. (1) \\
\hline сегнути, гл. (1) & седети, гл. (1) & сезам, им. (1) & сезати, гл. (1) \\
\hline сезати, гл. (1) & семе, им. (1) & серафим, им. (1) & сести, гл. (1) \\
\hline сести, гл. (1) & сетан, прид. (1) & сећање, им. (1) & сећати (се), гл. (1) \\
\hline сећати (се), гл. (1) & сибирски, прид. (1) & сив, прид. (1) & сигурно, прил. (1) \\
\hline сигурно, прил. (1) & сијати (се), гл. (1) & силан, прид. (1) & син, им. (1) \\
\hline син, им. (1) & сињи, прид. (1) & сипа, им. (1) & сиренин, прид. (1) \\
\hline сиренин, прид. (1) & сјај, им. (1) & сјајан, прид. (1) & сјуривати (се), гл. (1) \\
\hline сјуривати (се), гл. (1) & скалар, им. (1) & скидати (се), гл. (1) & склизнути, гл. (1) \\
\hline склизнути, гл. (1) & скоро, прил. (1) & скотурати (се), гл. (1) & скочити, гл. (1) \\
\hline
\end{tabular}




\begin{tabular}{|c|c|c|c|}
\hline скочити, гл. (1) & скренути, гл. (1) & $\begin{array}{l}\text { скривати (се), гл. } \\
\text { (1) }\end{array}$ & скрит, прид. (1) \\
\hline скрит, прид. (1) & скровиште, им. (1) & скупљати (се), гл. (1) & славити, гл. (1) \\
\hline славити, гл. (1) & славуј, им. (1) & слагати, гл. (1) & сладак, прид. (1) \\
\hline сладак, прид. (1) & сласт, им. (1) & сластан, прид. (1) & сластвен, прид. (1) \\
\hline сластвен, прид. (1) & слеп, прид. (1) & сличност, им. (1) & словесан, прид. (1) \\
\hline словесан, прид. (1) & слог, им. (1) & слуга, им. (1) & слутити, гл. (1) \\
\hline слутити, гл. (1) & случити (се), гл. (1) & смалаксан, прид. (1) & смалаксати, гл. (1) \\
\hline смалаксати, гл. (1) & смарагдни, прид. (1) & смех, им. (1) & смешан, прид. (1) \\
\hline смешан, прид. (1) & смештен, прид. (1) & смирити (се), гл. (1) & смислити, гл. (1) \\
\hline смислити, гл. (1) & смрт, им. (1) & спадати, гл. (1) & спазити, гл. (1) \\
\hline спазити, гл. (1) & $\begin{array}{l}\text { спарушити (се), } \\
\text { гл. (1) }\end{array}$ & спати, гл. (1) & спевати, гл. (1) \\
\hline спевати, гл. (1) & Спиноза, им. (1) & сплести (се), гл. (1) & спокој, им. (1) \\
\hline спокој, им. (1) & $\begin{array}{l}\text { спомен-светиња, } \\
\text { им. (1) }\end{array}$ & спочетка, прил. (1) & спреман, прид. (1) \\
\hline спреман, прид. (1) & $\begin{array}{l}\text { спустити (се), гл. } \\
\text { (1) }\end{array}$ & сребрн, прид. (1) & средњи, прид. (1) \\
\hline средњи, прид. (1) & срница, им. (1) & сродан, прид. (1) & срубљен, прид. (1) \\
\hline срубљен, прид. (1) & срча, им. (1) & срчан, прид. (1) & ставити, гл. (1) \\
\hline ставити, гл. (1) & ствар, им. (1) & стварати, гл. (1) & створ, им. (1) \\
\hline створ, им. (1) & створеност, им. (1) & степа, им. (1) & стерилан, прид. (1) \\
\hline стерилан, прид. (1) & стизати, гл. (1) & стинути, гл. (1) & $\begin{array}{l}\text { стишавати (се), } \\
\text { гл. (1) }\end{array}$ \\
\hline $\begin{array}{l}\text { стишавати (се), } \\
\text { гл. (1) }\end{array}$ & сто, им. (1) & стража, им. (1) & страстан, прид. (1) \\
\hline страстан, прид. (1) & страх, им. (1) & страхотан, прид. (1) & Стрелац, им. (1) \\
\hline Стрелац, им. (1) & стригнути, гл. (1) & $\begin{array}{l}\text { стрмен, им. / пои- } \\
\text { меничени прид. (1) }\end{array}$ & стрмо, прил. (1) \\
\hline стрмо, прил. (1) & строг, прид. (1) & стрпљиво, прил. (1) & струјати, гл. (1) \\
\hline струјати, гл. (1) & струјити, гл. (1) & стуб, им. (1) & студ, им. (1) \\
\hline студ, им. (1) & студан, прид. (1) & ступати, гл. (1) & ступити, гл. (1) \\
\hline ступити, гл. (1) & судбина, им. (1) & суђен, прид. (1) & сузити (се), гл. (1) \\
\hline
\end{tabular}




\begin{tabular}{|c|c|c|c|}
\hline сузити (се), гл. (1) & сујета, им. (1) & сукња, им. (1) & сулуд, прид. (1) \\
\hline сулуд, прид. (1) & сумњати, гл. (1) & $\begin{array}{l}\text { суновратан, прид. } \\
\text { (1) }\end{array}$ & сустао, прид. (1) \\
\hline сустао, прид. (1) & тајанствен, прид. (1) & тајга, им. (1) & таласати (се), гл. (1) \\
\hline таласати (се), гл. (1) & тамнина, им. (1) & танак, прид. (1) & танан, прид. (1) \\
\hline танан, прид. (1) & танахан, прид. (1) & тачан, прид. (1) & таштина, им. (1) \\
\hline таштина, им. (1) & творчев, прид. (1) & тврдити, гл. (1) & тегобан, прид. (1) \\
\hline тегобан, прид. (1) & тесан, прид. (1) & тећи, гл. (1) & тешко, прил. (1) \\
\hline тешко, прил. (1) & титрав, прид. (1) & тих, прид. (1) & тморан, прид. (1) \\
\hline тморан, прид. (1) & тмуран, прид. (1) & толико, прил. (1) & топаз, им. (1) \\
\hline топаз, им. (1) & топот, им. (1) & точити, гл. (1) & траг, им. (1) \\
\hline траг, им. (1) & трак, им. (1) & трем, им. (1) & трен, им. (1) \\
\hline трен, им. (1) & тренутак, им. (1) & трепет, им. (1) & трепкати, гл. (1) \\
\hline трепкати, гл. (1) & трептав, прид. (1) & трећи, прид. (1) & трон, им. (1) \\
\hline трон, им. (1) & тронуће, им. (1) & трунка, им. (1) & трупкати, гл. (1) \\
\hline трупкати, гл. (1) & трчкарати, гл. (1) & тршав, прид. (1) & тужно, прил. (1) \\
\hline тужно, прил. (1) & тулити, гл. (1) & тумач, им. (1) & туробан, прид. (1) \\
\hline туробан, прид. (1) & ћебад, им. (1) & ћув, им. (1) & угаснути, гл. (1) \\
\hline угаснути, гл. (1) & угустити (се), гл. (1) & угушити (се), гл. (1) & удесно, прил. (1) \\
\hline удесно, прил. (1) & удивљен, прид. (1) & ужарен, прид. (1) & ужас, им. (1) \\
\hline ужас, им. (1) & ужас-око, им. (1) & ужгати, гл. (1) & узбуђење, им. (1) \\
\hline узбуђење, им. (1) & уздисати, гл. (1) & узмаштати, гл. (1) & узмоћи, гл. (1) \\
\hline узмоћи, гл. (1) & украшен, прид. (1) & укриће, им. (1) & укрстити (се), гл. (1) \\
\hline укрстити (се), гл. (1) & улево, прил. (1) & уље, им. (1) & умети, гл. (1) \\
\hline умети, гл. (1) & умирати, гл. (1) & умирен, прид. (1) & умрли, прид. (1) \\
\hline умрли, прид. (1) & уназад, прил. (1) & уписати (се), гл. (1) & упрегнути, гл. (1) \\
\hline упрегнути, гл. (1) & уронити, гл. (1) & усамљен, прид. (1) & усамљеник, им. (1) \\
\hline усамљеник, им. (1) & усмерив, прид. (1) & усна, им. (1) & уснути, гл. (1) \\
\hline уснути, гл. (1) & уснуће, им. (1) & уста, им. (1) & устрашен, прид. (1) \\
\hline устрашен, прид. (1) & усхит, им. (1) & усхићен, прид. (1) & утеха, им. (1) \\
\hline
\end{tabular}




\begin{tabular}{|l|l|l|l|}
\hline утеха, им. (1) & утисак, им. (1) & утробин, прид. (1) & утрти (се), гл. (1) \\
\hline утрти (се), гл. (1) & ући, гл. (1) & уши, им. (1) & ушица, им. (1) \\
\hline ушица, им. (1) & фин, прид. (1) & фотон, им. (1) & хајкач, им. (1) \\
\hline хајкач, им. (1) & хватати, гл. (1) & Херкул, им. (1) & химна, им. (1) \\
\hline химна, им. (1) & Хирошима, им. (1) & хитнут, прид. (1) & хладноћа, им. (1) \\
\hline хладноћа, им. (1) & ходање, им. (1) & хор, им. (1) & хоризонт, им. (1) \\
\hline хоризонт, им. (1) & хтење, им. (1) & хуј, им. (1) & хујати, гл. (1) \\
\hline хујати, гл. (1) & царевати, гл. (1) & царствен, прид. (1) & цветан, прид. (1) \\
\hline цветан, прид. (1) & цикање, им. (1) & цикати, гл. (1) & циклоида, им. (1) \\
\hline циклоида, им. (1) & чабрица, им. (1) & чамац, им. (1) & чамити, гл. (1) \\
\hline чамити, гл. (1) & чар, им. (1) & чаролија, им. (1) & чаршавиште, им. (1) \\
\hline чаршавиште, им. (1) & част, им. (1) & чежња, им. (1) & чело, им. (1) \\
\hline чело, им. (1) & чергар, им. (1) & чигра, им. (1) & чин, им. (1) \\
\hline чин, им. (1) & чист, прид. (1) & човечији, прид. (1) & чудовиште, им. (1) \\
\hline чудовиште, им. (1) & чука, им. (1) & џин, им. (1) & шапнути, гл. (1) \\
\hline шапнути, гл. (1) & шаптати, гл. (1) & шара, им. (1) & шетати, гл. (1) \\
\hline шетати, гл. (1) & шиб, им. (1) & ширити (се), гл. (1) & широко, прил. (1) \\
\hline широко, прил. (1) & шиштнути, гл. (1) & штур, прид. (1) & шумети, гл. (1) \\
\hline шумети, гл. (1) & шумити, гл. (1) & шумски, прид. (1) & шуштањ, им. (1) \\
\hline шуштањ, им. (1) & шуштати, гл. (1) & шчепати (се), гл. (1) & \\
\hline
\end{tabular}

Райна М. Драгичевич

Милош В. Утвич

\section{ПОЭТИЧЕСКИЙ СЛОВАРЬ ИРЕНЫ ГРИЦКАТ}

\section{Резюме}

В этой статье рассматриваем выбор лексики в стихами Ирены Грицкат Циклоида и указываем на связь между ее поэзией, особенно словарным запасом, с выводами в ее лингвистических исследованиях и в сочинениях посвященных науке и духовности. В этой статье также представлен частотный словарь автосемантических лексем, используемых в стихах Ирены Грицкат, который обеспечивает более легкий доступ к данным. 